\title{
Peran Parenting dalam Meningkatkan Literasi Kesehatan Ibu terhadap Stunting di Bangkalan Madura
}

\author{
Siti Fadjryana Fitroh ${ }^{1}$, Eka Oktavianingsih ${ }_{2}$ \\ Pendidikan Guru Pendidikan Anak Usia Dini, Universitas Trunojoyo \\ DOI: $\underline{10.31004 / \text { obsesi.v4i2.415 }}$
}

\begin{abstract}
Abstrak
Literasi kesehatan bagi ibu sangat penting terutama perihal gizi dan kesehatan anak, mengingat maraknya kasus stunting yang menimpa anak di Indonesia. Penyebab tingginya kasus stunting, khususnya di Bangkalan, Madura adalah pengetahuan ibu yang rendah dalam hal parenting (merawat, mendidik, membimbing). Penelitian ini bertujuan untuk: (1) mengetahui efektivitas kegiatan parenting education guna meningkatkan pengetahuan ibu muda terkait status gizi selama masa kehamilan, dan (2) mengetahui faktor pendukung dan penghambat dalam kegiatan parenting education. Penelitian ini menggunakan pendekatan mixed method (metode campuran) dengan teknik wawancara, dokumentasi, observasi, dan tes yang hasilnya akan dianalisis secara kualitatif dan kuantitatif. Hasil analisis data menunjukkan kegiatan parenting education untuk pencegahan stunting dinyatakan efektif berdasarkan perhitungan uji-t sehingga terdapat perbedaan signifikan antara pengetahuan ibu muda sebelum dan sesudah mengikuti parenting education.
\end{abstract}

Kata Kunci: stunting; ibu muda; parenting education; literasi kesehatan.

\begin{abstract}
Health literacy for mothers is very important regarding nutrition and child health, given the stunting problem that befell children in Indonesia. The cause of elevating the problem of stunting, especially in Bangkalan, Madura is the low maternal knowledge in terms of parenting (caring, educating, guiding). This study aims to: (1) determine the problems of parenting education activities in order to increase maternal knowledge related to nutritional status during pregnancy, and (2) determine the supporting and inhibiting factors in parenting education activities. This research used a mixed method with interview, documentation, observation, and test techniques that will be analyzed qualitatively and quantitatively. The results of data analysis showed that parenting education activities to question stunting were declared effective in t-test calculations so that they were considered significant among young mothers' knowledge before and after participating in parenting education..
\end{abstract}

Keywords: stunting; young mothers; parenting education; health literacy.

Copyright (c) 2020 Siti Fadjryana Fitroh, Eka Oktavianingsih

$\triangle$ Corresponding author :

Email Address : eka.oktavianingsih@trunojoyo.ac.id (Bangkalan, Madura, Indonesia)

Received 6 January 2020, Accepted 13 january 2020, Published 16 January 2020 


\section{PENDAHULUAN}

Akhir-akhir ini di Indonesia banyak ditemukan permasalahan kaitannya dengan anak pendek (stunting). Data di lapangan menyatakan bahwa Indonesia masuk dalam kategori jumlah balita yang mengalami stunting dengan urutan ke tiga di tingkat Regional Asia Tenggara/South-East Asia Regional (SEAR) data ini diperoleh berdasarkan World Health Organization (WHO) yang menjelaskan di tahun 2005-2017 tercatat prevalensi balita stunting Indonesia sebanyak $36,4 \%$. Selain itu dalam kurun waktu tiga tahun terakhir menurut Pemantauan Status Gizi (PSG) pendek mengalami prevalensi tinggi jika dibandingkan dengan permasalahan status gizi lainnya seperti gizi kurang, kurus, dan gemuk. Peningkatan balita pendek tercatat tahun 2016 dari 27,5 \% meningkat menjadi 29,6\% di tahun 2017. Secara khusus, di Provinsi Jawa Timur, dinyatakan 10 bayi lahir di tiap harinya dengan memiliki berat badan rendah dan hampir $36 \%$ anak di bawah usia lima tahun rawan mengalami stunting (UNICEF, 2013).

Di Kabupaten Bangkalan Madura, pada tahun 2015, terdapat 240 balita yang mengalami gizi buruk (marasmus, kwashiorkor, kurus, stunting), di mana meningkat sebanyak 36 balita dari tahun 2014 (Dinas Kesehatan Kabupaten Bangkalan, 2015).Berdasarkan data terbaru hasil wawancara terhadap tenaga medis pada 6 Puskesmas di Kabupaten Bangkalan pada bulan Juni sampai dengan Agustus 2019, ditemukan bahwa jumlah kasus balita stunting di Puskesmas Kamal sebanyak 309 kasus, di Puskesmas Socah sebanyak 113 kasus, Puskesmas Bangkalan sebanyak 536 kasus, Puskesmas Burneh sebanyak 79 kasus, Puskesmas Arosbaya sebanyak 260 kasus, dan Puskesmas Tanah Merah sebanyak 95 kasus. Penyebab stunting yang paling dominan adalah rendahnya kesadaran masyarakat terutama $\mathrm{ibu} / \mathrm{ibu}$ hamil tentang pentingnya zat gizi dalam makanan dan mengganggap makanan yang dikonsumsi cukup mengenyangkan. Selain itu, bayi yang diberikan ASI eksklusif di Bangkalan hanya sebesar 49,8\% (Dinas Kesehatan Kabupaten Bangkalan, 2015).

Stunting merupakan status gizi kurang yang bersifat kronik pada masa pertumbuhan dan perkembangan yang dipresentasikan melalui nilai z-score tinggi badan menurut umur (TB/U) kurang dari -2 standar deviasi (SD) berdasarkan standar pertumbuhan (World Health Organization, 2010). Dalam permasalahan gizi, terutama stunting pada anak perlu mendapatkan perhatian lebih karena akan mempengaruhi perkembangan serta menimbulkan dampak negative. Menurut Kementerian Desa, Pembangunan Daerah Tertinggal (2017) hal yang akan dialami anak stunting seperti gangguan (otak, kecerdasan, pertumbuhan fisik, dan metabolism tubuh), menurunnya (kemampuan kognitif, prestasi belajar dan kekebalan tubuh). Terdapat beberapa ciri anak mengalami stunting, di antaranya: (1) Wajah terlihat lebih muda dari usianya; (2) Keterlambatan dalam pertumbuhan; (3) Lambatnya pertumbuhan gigi; (4) Tidak maksimalnya tingkat perhatian dan memori belajar; (5) Mengalami keterlambatan pubertas; dan (6) Menjadi pendiam dan tidak banyak melakukan eye contact di usia 8-10 thun. Ciri-ciri anak yang mengalami stunting tidak terjadi begitu saja, sudah ditunjukkan lewat tanda pra-konsepsi seorang remaja menjadi ibu yang kurang gizi seperti saat hamil kurang mendapatkan asupan gizi yang cukup, mengalami anemia dan tinggal di lingkungan dengan sanitasi kurang memadai. Gangguan kesehatan dan perkembangan janin yang disebabkan oleh kekurangan asupan gizi ( $\mathrm{Fe}$, asam folat, hemoglobin) akan menyebabkan bayi lahir dengan berat badan rendah (Rukmana, 2013).

Kecukupan nutrisi pada ibu hamil dipengaruhi oleh tinggi rendahnya pengetahuan ibu akan pentingnya memperhatikan gizi selama masa kehamilan (Nurhidayati \& Ernawati, 2016). Menurut Silas, Rantetampang, Tingginehe, \& Mallongi (2018) pengetahuan dan peran orangtua menjadi faktor yang signifikan, dan pengetahuan menjadi dominan dengan insiden stunting pada anak di bawah usia 5 tahun. Apabila seorang ibu dengan ilmu pengetahuan gizi dan kesehatan baik, maka ibu akan memiliki perilaku sehat yang tepat dalam memilih konsumsi makanan gizi seimbang terhadap diri dan janinya Hal ini sejalan dengan 
penelitian Primivita Dirgahayu (2015) menjelaskan bahwa terdapat hubungan antara tingakat pengetahuan yang dimiliki dengan perilaku hidup bersih dan sehat.

Berdasarkan survei awal terhadap 6 puskesmas di Kabupaten Bangkalan, puskesmas selama ini telah memberikan penyuluhan dan pendampingan terkait pencegahan dan penanganan stunting. Akan tetapi, program tersebut belum menyeluruh dan konsisten, serta konten dari penyuluhan belum menyentuh ranah pentingnya peran orangtua. Selain itu, masyakarat kurang memiliki kemampuan dan keterampilan bagaimana cara memperoleh informasi, memahami menganalisa, sampai dengan memberi penilaian akan kebermanfaatan informasi yang sudah didapatkan. Padahal, apabila orangtua dapat memanfaatkan informasi dari buku atau majalah, kemudian sumber lain berasal staff sekolah, teman, televisi, dan internet (Radey \& Randolph, 2009).

Berkaitan pentingnya kesehatan untuk masyarakat maka diperlukan sebuah solusi atau formula untuk masyarakat dapat mengakses dan mengolah informasi kesehatan dengan benar dan tepat, sehingga dapat membantu dalam pemecahan masalah dan pembuatan keputusan. Iriantara \& Soenendar (2010) menjelaskan bahwa pemahaman tentang literasi kali ini tidak hanya sekedar kemampuan dalam membaca ataupun menulis, karena menulis "teks" sudah diperluas cakupannya dalam bentuk visual, audiovisual serta kecangihan dimensi komputerisasi, sehingga dalam pemahaman "teks" terdapat unsur kognitif, afektif dan intuitif. Adapun literasi sendiri dibagi menjadi 9 yakni yakni literasi (kesehatan, finansial, data, digital, kritikal, visual, statistik, teknologi dan informasi).

Literasi kesehatan dapat membantu meningkatkan kualitas kesehatan, kesejahteraan, serta meminimalisir resiko dan kesenjangan kesehatan (World Health Organization, 2010). Bagian dari kemampuan yang dimiliki seseorang memperoleh, memproses serta memahami sebuah informasi kesehatan dan kebutuhan pelayanan guna mengambil keputusan yang tepat dalam kesehatan (Zoellner et al., 2011). Literasi kesehatan dibagi menjadi beberapa tingkatan dalam perananya sebagai pemberdayaan diantaranya adalah: 1) tingkat dasar berupa kemampuan dasar untuk membaca dan memahami petunjuk perintah perawatan; 2) tingkat menengah yakni seseorang memiliki kemampuan dalam mengaitkan pengetahuan awal dengan informasi yang ada di lingkungan; 3) tingkat tinggi yakni kemampuan seseorang dalam menilai sebuah informasi yang diterima lalu diinformasikan kembali kepada orang lain sebagai bentuk pengembangan informasi di bidang kesehatan.

Apabila ibu, sebagai bagian kecil dari masyakarat memiliki literasi kesehatan maka akan menjadi solusi dari banyaknya permasalahan tentang kesehatan dan gizi anak. Permasalahan ini berkaitan dengan status gizi yang merupakan salah satu indikator dalam Pembangunan dengan Tujuan Berkelanjutan atau Sustainable Development Goals (SDG). Hal ini sangat krusial dan harus mendapat perhatian khusus guna peningkatan sumber daya manusia yang sehat di masa mendatang. Menurut Almatsier (2001) memaparkan bahwa status gizi merupakan ukuran dari kondisi tubuh yang dapat diamati dari apa yang dikonsumsi dan beberapa penggunaan zat gizi didalam tubuh. Adapun sebuah cara yang menurut Supariasa, 2012 dalam memberikan penilaian status gizi pada individu yakni secara langsung lewat antropometri, klinis, biofisik dan biokimia, ataupun secara tidak langsung lewat survey konsumsi makanan, statistic vital dan factor ekologi. Status gizi pada anak salah satunya ditentukan oleh peran ibu, khususnya ibu yang sedang program hamil atau sudah hamil. Status gizi ibu hamil memiliki pengaruh penting terhadap: (1) kemampuan untuk hamil, (2) kesehatan bayi yang dilahirkan, (3) kejadian bayi lahir prematur dan memiliki berat badan kurang, (4) kesehatan lanjut bayi, dan (5) kesehatan keturunan selanjutnya (Albon \& Mukherji, 2008). Alasan tersebut mendasari mengapa status gizi ibu hamil penting untuk diperhatikan. Menurut Almatsier (2001) status gizi dibagi menjadi empat kategori, yaitu berat kurang (underweight), pendek (stunting), kurus (wasting), dan gemuk (obesitas). 
Stunting dapat dicegah sedini mungkin melalui upaya meningkatkan literasi kesehatan ibu muda akan pentingnya memperhatikan status gizi selama masa pra kehamilan, kehamilan, dan post kelahiran atau selama 1000 Hari Pertama Kehidupan (HPK). Selama ini, upaya pencegahan dan penanganan stunting telah dilakukan oleh pihak Puskesmas di Bangkalan, Madura antara lain: penyuluhan namun hanya sebatas pada informasi kesehatan dan bahaya stunting. Hal ini dirasakan belum efektif karena belum menyentuh ranah kesadaran kaitannya dengan (peran, tugas dan kewajiban) dalam pengasuhan. Program yang dirasa peneliti tepat untuk diintegrasikan dengan menumbuhkan literasi kesehatan adalah program parenting education.

Program parenting education merupakan bentuk kegiatan berupa dukungan yang diberikan untuk orangtua agar memiliki kemampuan melaksanakan fungsi sosial mereka dalam hal mengasuh, merawat, melindungi, dan mendidik anaknya. Dari program tersebut, harapannya anak masa depan secara optimal bisa tumbuh dan berkembang sesuai dengan tahapan usia perkembangannya dan mendapatkan standar perolehan kesehatan dan gizi yang baik. Adapun manfaat yang dapat diperoleh dari program parenting education yakni menemukan solusi lewat sebuah komunikasi interaktif yang baik tentang perkembangan anak, dan hak- seperti apa yang harus dipenuhi orangtua dalam kelangsungan hidup anak. Tujuan program parenting education dalam kesehatan dan gizi akan diupayakan melalui pengembangan materi yang menurut Direktorat Pembinaan Pendidikan Anak Usia Dini tahun 2012 mencakup 6 (enam) bahasan, yaitu: (1) peningkatan gizi, (2) pemeliharaan kesehatan, (3) perawatan, (4) pengasuhan, (5) pendidikan, dan (6) perlindungan. Enam materi di atas akan dijadikan poin dasar dalam kegiatan parenting education.

Membaca pepamaran di atas, permasalahan berkaitan dengan literasi kesehatan pada masyarakat, untuk dapat mengetahui secara jelas diperlukan sebuah penilaian. Penilaian tentang literasi kesehatan ini di integrasikan lewat sebuah program parenting education. Sehingga tujuan dari penelitian ini lebih difokuskan pada keingin tahuan peneliti pada : 1) efektivitas program parenting education guna meningkatkan literasi kesehatan yang tergambar dari pengetahuan ibu muda terkait status gizi $1000 \mathrm{HPK}$, dan 2) faktor-faktor pendukung dan penghambat selama kegiatan parenting education kepada ibu muda sebagai upaya preventif dalam permasalahan stunting.

\section{METODOLOGI}

Model penelitian ini termasuk kategori penelitian campuran (mixed method) dengan embedded experimental model. Peneliti menggunakan alat pengumpul data yang beragam sehingga data atau fakta yang diperoleh lebih komprehensif dan menyeluruh. Model mixed method digunakan dalam menjawab dua rumusan masalah penelitian, baik secara kuantitatif maupun kualitatif. Responden yang terlibat dalam penelitian ini adalah ibu muda sebanyak 111 ibu muda yang dipilih melalui teknik purposive random sampling.

Menjawab rumusan masalah pertama, fase model eksperimen dalam penelitian ini adalah desain one group pretest-postest. Pada desain ini, semua subjek melalui perlakuan selama satu kali (Nahartyo, 2013). Hasil dari penelitian akan lebih akurat karena dibandingkan dari hasil sebelum dan sesudah perlakuan (Sugiyono, 2001).

\begin{tabular}{|lll|}
\hline $\mathrm{O}_{1}$ & $\mathrm{X}$ & $\mathrm{O}_{2}$ \\
\hline
\end{tabular}

Gambar 1. Desain eksperimen (one group pretest-postest).

Keterangan

O1 : Kondisi sebelum perlakuan

$\mathrm{X}$ : Perlakuan

O2 : Kondisi setelah perlakuan. 
Variabel terikat pada penelitian ini adalah literasi kesehatan ibu muda tentang pencegahan stunting. Variabel bebasnya adalah pelaksanaan program parenting education bagi ibu muda. Untuk menjawab rumusan masalah kedua lebih menggunakan metode kualitatif yakni sebuah penelitian yang focus menggambarkan objek penelitian berdasarkan fakta-fakta yang diperoleh apa adanya di lapangan (Mukhtar, 2013).

Pengukuran dari variabel terikat, literasi kesehatan ibu muda, adalah dengan tes yang sudah divalidasi oleh ahli, dalam hal ini ahli kesehatan dan ahli evaluasi. Instrumen digunakan untuk mengukur pengetahuan ibu muda tentang stunting mulai dari pengertian, penyebab, dampak dan pencegahan stunting. Tes terdiri dari 30 aitem dengan menggunakan skala Guttman dengan empat alternatif jawaban. Dengan total skor adalah 100. Dalam pengumpulan data mengunakan observasi dan wawancara. Observasi jenis partisipan digunakan peneliti guna mendapatkan informasi secara langsung dengan cara ikut terlibat langsung dalam kegiatan dengan seluruh peserta kegiatan parenting education, sedangkan wawancara jenis tidak terstuktur, dimana pertanyaan yang diajukan secara spontan berdasarkan apa yang ingin peneliti tanyakan yang mana pertanyaan tetap sesuai topik penelitian. Wawancara dilakukan langsung pada peserta kegiatan parenting serta perwakilan dari dinas kesehatan, masing-masing kecamatan ada 2 sampai 3 perwakilan.

Dalam analisis data peneliti menggunakan uji normalitas dan uji hipotesis menggunakan SPSS. 21. Uji normalitas digunakan untuk menentukan distribusi data dan menentukan teknik statistik yang akan digunakan pada tahap selanjutnya. Peneliti menggunakan uji One Kolmogorov-Smirnov Test dengan level signifikansi (a) 5\% atau 0.05. Uji hipotesis dilakukan dengan menggunakan Paired T-test yang bertujuan untuk melihat perbedaan pengetahuan ibu muda sebelum dan sesudah mengikuti kegiatan parenting.

Analisis data kualitatif dengan melalui proses mulai dari (1) data reduction, yaitu memilih dan memilah data yang akan dianalisis berupa kata, kalimat, atau ungkapan sesuai dengan metode; (2) data display, yaitu menampilkan data yang telah dipilih dan dipilahpilah dan menganalisis jenis metode; (3) verification, yaitu menyimpulkan hasil analisis terhadap penggunaan metode (Mukhtar, 2013).

\section{HASIL DAN PEMBAHASAN}

\section{Literasi Kesehatan Ibu Muda}

Penelitian ini menilai literasi kesehatan ibu muda yang diperoleh dari aspek kognitif melalui respon dari tes. Tes diberikan selama dua kali, sebelum dan sesudah ibu muda mengikuti kegiatan parenting. Hasil dari pretest dan postest tersajikan dalam Tabel 1.

Tabel 1. Hasil Uji Normalitas

One-Sample Kolmogorov-Smirnov Test

\begin{tabular}{|ll|r|r|}
\hline & & Sebelum & Sesudah \\
\hline $\mathrm{N}$ & Mean & 112 & 112 \\
Normal Parametersa,b & Std. & 60,17857 & 81,19048 \\
& Deviation & & \\
& Absolute &, 106 &, 125 \\
Most Extreme & Positive &, 056 &, 058 \\
Differences & Negative &,- 106 &,- 125 \\
Kolmogorov-Smirnov Z & 1,119 & 1,326 \\
Asymp. Sig. (2-tailed) &, 163 &, 059 \\
\hline
\end{tabular}

a. Test distribution is Normal.

b. Calculated from data. 
Berdasarkan kondisi pretest, nilai rerata sebesar 60.17857 dengan standar deviasi 17.374399. Hasil postest dengan rerata 81.19048 dengan standar deviasi 10.520557. Berdasarkan data pada tabel 1, menunjukkan bahwa ada perubahan rerata skor literasi kesehatan ibu muda sebelum dan sesudah mengikuti kegiatan parenting. Berdasarkan tabel, nilai dari sig. (2-tailed) adalah 0,163 (untuk pretest) dan 0,059 (untuk postest). Dengan menggunakan taraf signifikansi (a) 5\% atau 0,05 maka persebaran data untuk uji normalitas baik pretest maupun postest dinyatakan normal. Hal tersebut dikarenakan nilai sig. (2-tailed) $>$ nilai a, yaitu 0,163>0,05 untuk pretest dan 0,059>0,05 untuk postest.

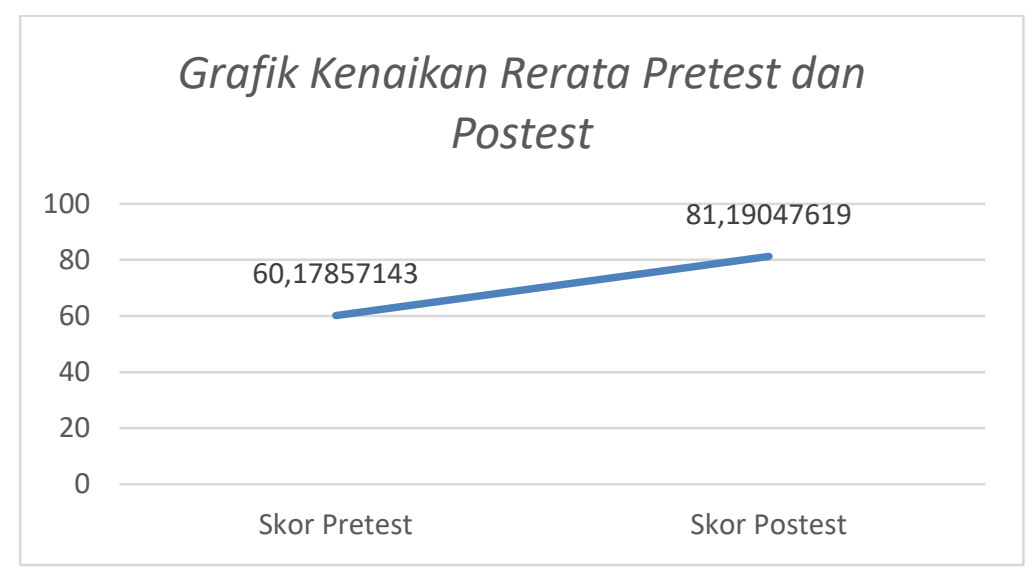

Gambar 2. Grafik Kenaikan Rerata Pretest dan Postest

Tabel 3. Hasil dari t-test literasi kesehatan ibu muda sebelum dan sesudah mengikuti kegiatan parenting

\begin{tabular}{|c|c|c|c|c|c|c|c|c|}
\hline & \multicolumn{5}{|c|}{ Paired Differences } & \multirow[b]{3}{*}{$t$} & \multirow[b]{3}{*}{ df } & \multirow[b]{3}{*}{ Sig. (2-tailed } \\
\hline & \multirow[b]{2}{*}{ Mean } & \multirow[b]{2}{*}{ Std. Deviation } & \multirow{2}{*}{$\begin{array}{c}\text { Std. Error } \\
\text { Mean }\end{array}$} & \multicolumn{2}{|c|}{$\begin{array}{l}95 \% \text { Confidence Interval of the } \\
\text { Difference }\end{array}$} & & & \\
\hline & & & & Lower & Upper & & & \\
\hline Pair 1 Sesudah - Sebelum & 21,011905 & 14,281871 & 1,349510 & 18,337761 & 23,686049 & 15,570 & 111 &, 000 \\
\hline
\end{tabular}

Tabel 3 menunjukkan hasil dari analisis uji t test menggunakan Paired Sample t-Test, baik pretest maupun postest. Nilai $t$ diperoleh 15.570. Nilai $t$ tabel senilai 1.98 diperoleh dari $\mathrm{dk}=(\mathrm{n}-1)=(111-1)=110$. Berdasarkan nilai dari $\mathrm{t}$ hitung $>\mathrm{t}$ tabel dan nilai $\mathrm{p}<0.05$, sehingga Ho ditolak. Oleh karena itu, skor pretest berbeda secara signifikan dari skor postest.

Berdasarkan perhitungan uji-t di atas, maka diperoleh nilai $\mathrm{p}=0,000$ sehingga nilai $\mathrm{p}<0,05$ dan Ha diterima. Karena nilai $\mathrm{p}<\mathrm{\alpha}$, maka dapat ditarik kesimpulan bahwa ada perbedaan yang signifikan pengetahuan subyek sebelum dan sesudah mengikuti program parenting education. Perubahan rerata pretest dan postest signifikan dengan perbedaan 21.011905. Hal ini berarti bahwa literasi kesehatan ibu muda dalam pencegahan stunting pada anak telah meningkat setelah berpartisipasi dalam kegiatan parenting education. Kenaikan skor terlihat secara signifikan. Hal ini berarti bahwa kegiatan parenting educaton dapat meningkatkan literasi kesehatan ibu muda dalam upaya pencegahan stunting.

Kenaikan pengetahuan ibu muda tentang pencegahan stunting setelah mengikuti program parenting sejalan dengan penelitian yang telah dilakukan oleh Child Welfare Information Gateway (2013) bahwa melalui program parenting education, pengasuh dan orangtua akan bertambah pengetahuan, sumber ilmu, dan dukungan dalam kemampuan menyediakan lingkungan positif sehingga anak akan optimal pertumbuhan fisik dan perkembangan bahasa serta emosinya. Barlow \& Coren (2018) dalam penelitiannya juga menyebutkan bahwa program parenting dapat meningkatkan dukungan psikososial orangtua demi kesejahteraan anak. Adapun dimensi kesejahteraan anak mencakup 
keseluruhan diantaranya: kesehatan fisik, perkembangan, keamanan, perkembangan emosi dan sosial, serta perkembangan kognitif (Moore, 2013).

Apabila pengetahuan ibu muda meningkat, maka ibu akan lebih mudah dalam melaksanakan tanggungjawabnya (Lopez, Tjokrosonto, \& Paramastri, 2004). Apabila dikaitkan dengan taksonomi Bloom, pengetahuan masuk ke dalam domain kognitif, di mana domain tersebut memiliki beberapa tingkatan, mulai dari mengetahui, memahami, mengaplikasikan, mensintesis, dan mengevaluasi (Hamzah \& Koni, 2014). Pada level pengetahuan, seseorang dapat menyebutkan, mengingat, memahami, dan mengulang informasi.

Program parenting education merupakan bagian dari kegiatan solusi, dimana subyek penelitian adalah ibu yang masuk kategori orang dewasa. Parenting education adalah bentuk kegiatan pendidikan untuk orang dewasa. Menurut Sudjana (2010) menjelaskan bahwa merupakan kegiatan untuk orang dewasa di sebuah lingkungan masyarakat, guna mengembangkan kemampuan, pengetahuan dan ketrampilan sehingga memiliki cara baru mengubah atau menyikapi sebuah sikap dan perilaku. Selain itu program parenting education dalam penelitian ini memiliki visi salah satunya memberikan pemahaman sekaligus penyamaan informasi seputar menjalankan fungsi sosialnya khususnya dalam mengasuh, merawat, melindungi dan mendidik anak sehingga dapat optimal dalam tubuh dan berkembangnya. Dan dapat tercapainya sebuah manfaat keberlangsungan kehidupan anak dalam kesehatan dan mempeloreh gizi seimbang dalam proses tubuh dan kembangnya lewat enam materi yang sudah dipaparkan oleh Direktorat Pembinaan Pendidikan Anak Usia Dini tahun 2012.

Keberhasilan sebuah program terletak pada efek dari penerima program, tidak lain adalah orang tua. Disini orang tua yang difokuskan pada ibu sebaiknya memiliki pengetahuan tentang gizi dan kesehatan untuk anaknya, sebagai upaya pencegahan stunting. Hal ini merupakan keharusan karena menurut penelitian Syahrul et al., (2016) dan Rachmi, Li, \& Alison Baur (2017) menyatakan bahwa ibu dengan pengetahuan rendah dan tingkat pendidikan rendah menjadi faktor terjadinya stunting pada anak. Apabila ibu memiliki pengetahuan yang cukup tentang kesehatan, maka pada level dasar, anak menjadi terpenuhi perawatan, perlindungan, sehingga khususnya berat badan yang ideal (National Research Council, 2015).

Hasil juga menunjukkan terdapat beberapa hal yang sering ditanyakan selama kegiatan oleh ibu-ibu kaitannya dengan 1) pengasuhan yang tepat; 2) cara memberikan tambahan gizi sesuai dengan makan lokal daerah dan, 3) cara menghindari status gizi buruk. Pertama, penjelasan tentang pengasuhan yang tepat dimulai dengan pertanyaan yang berkaitan dengan kesalahan-kesalahan pola pengasuhan lama yang masih diterapkan di zaman sekarang, dan saat diberikan informasi yang benar membuat sadar bahwa cara tersebut sudah tidak tepat digunakan dalam pengasuhan. Hal ini memberikan kesadaran tersendiri bagi ibu untuk evaluasi diri dari apa yang sudah dilakukan dan berdampak terhadap perkembangan anak. Kedua, cara memilih makanan yang tepat dan bisa digunakan sebagai tambahan gizi menyesuaikan dengan kemampuan ekonomi dan kemudahan dalam mencari atau ada di sekitar tempat tinggal (mudah dijangkau dalam memperolehnya). Hal ini menjadi penting karena mengingat sebagian besar kasus stunting berasal dari ketahanan pangan rumah tangga yang buruk (Fadzila \& Tertiyus, 2019). Caranya adalah cukup menerapkan apa yang sudah di informasikan oleh bidan sebelumnya misalnya berkaitan dengan pemenuhan nutrisi dan gizi (karbohidrat, vitamin, protein, kalsium dan zat besi) atau hal yang dibutuhkan waktu masa prenatal (kehamilan) dan masa postnatal (tumbuh kembang). Tahap awal bisa dilakukan dengan mengkategorikan makanan dan minuman baik dan tidak baik untuk kesehatan waktu masa prenatal dan masa postnatal yang mudah dijangkau, selain itu pastikan kesehatan dan gizi terpenuhi di 1000 Hari Pertama Kehidupan (HPK) agar anak dapat tumbuh dan berkembang optimal. Dengan kata lain, status nutrisi selama kehamilan menjadi prediktor kuat dalam pertumbuhan dan 
perkembangan pada 1000 hari pertama kehamilan dan juga mempengaruhi kerentanan penyakit ketika dewasa (Wrottesley, Lamper, \& Pisa, 2016). Ketiga, cara menghindari status gizi dalam hal ini stunting adalah pola asuh yang tepat (mendidik, merawat, membimbing); pola makan (pemberian makanan sesuai dengan takaran, frekuensi dan variasi); dan air bersih dan sanitasi. Hal tersebut apabila dikaitkan dengan penelitian Alkon \& Cole (2012), masuk ke dalam kesehatan dan keselamatan anak usia dini yang mencakup hidup bersih dan sanitasi, persiapan dan pemberian makanan, dan pola tidur anak.

Program parenting education sebaiknya dilaksanakan secara rutin dan konsisten atau dapat menjadi program bulanan di puskesmas, dengan harapan dapat mengurangi fenomena permasalahan status gizi di wilayah Madura. Terlebih orangtua merupakan sumber daya untuk dihargai dan dibangun berdasarkan pertimbangan perancang program, baik pemerintah maupun stakeholder (Tomlinson \& Andina, 2015). Bagi pengembang program, juga perlu diperhatikan untuk mengenali dan mendorong tradisi dan nilai-niai orangtua.

Faktor penghambat yang ditemui selama kegiatan parenting education kepada ibu muda sebagai upaya preventif dalam permasalahan stunting selama kegiatan yakni: ketidaktersediaan sarana dan prasarana (kursi dan papan), waktu dan durasi pelaksanaan program, serta status pendidikan ibu. Adapun faktor pendukung keberhasilan program parenting education antara lain: kemenarikan materi, dan kerjasama stakeholder. Kerjasama dari stakeholder yakni pegawai puskesmas menjadi faktor utama. Bentuk keterlibatan dapat ditunjukkan melalui dukungan moril kegiatan mulai awal hingga akhir pelaksanaan. Dan kegiatan ini dapat berkelanjutan dilakukan oleh stakeholder secara rutin dan maksimal sebagai upaya pencegahan fenomena stunting. Hal ini senada dengan apa yang diungkapkan oleh Bergström et al., (2015) yang menjelaskan peran penting kerjasama antar pihak dalam menjalankan program akan menghasilkan proyek yang sesuai.

\section{SIMPULAN}

Berdasarkan hasil penelitian di atas dapat disimpulkan bahwa kegiatan parenting education dinyatakan efektif dalam meningkatkan literasi kesehatan ibu dalam pencegahan stunting. Berkat dukungan stakeholder dan kemenarikan materi, bu-ibu muda menjadi lebih paham bagaimana mencegah stunting pada anak. Beberapa rekomendasi untuk penelitian selanjutnya, antara lain: (1) diperlukan standar kategori tingkatan kasus stunting dilihat dari jumlah kasus keseluruhan di Bangkalan; (2) diperlukan adanya instrumen yang mengukur respon ibu muda (pengguna) terhadap kegiatan yang sudah dilakukan puskesmas; (3) perlu keterlibatan anggota keluarga terutama orangtua (ayah dan ibu); (4) perlu peran aktif dari puskesmas untuk membantu proses pelaksanaan kegiatan; serta (5) setiap pelaksanaan diberikan durasi waktu agar lebih terstruktur.

\section{UCAPAN TERIMAKASIH}

Ucapan terimakasih peneliti sampaikan kepada Universitas Trunojoyo Madura, Dinas Kesehatan Kabupaten Bangkalan, puskesmas Socah, puskesmas Burneh, puskesmas Arosbaya, puskesmas Tanah Merah, puskesmas Kamal, serta seluruh ibu muda yang telah berpartisipasi dalam penelitian ini.

\section{DAFTAR PUSTAKA}

Albon, D., \& Mukherji, P. (2008). Food and Health in Early Childhood: A Holistic Approach. London: Sage Publications Ltd.

Alkon, A., \& Cole, P. S. (2012). Assessing Indiana's Health and Safety in Early Care and Education Programs : Identifying Areas for Improvement. Maternal Child Health Journal, 555-563. https:/ / doi.org/10.1007/s10995-011-0788-7

Almatsier, S. (2001). Prinsip-prinsip dasar ilmu gizi. Jakarta: Gramedia Pustaka Utama. 
Bangkalan, D. K. K. (2015). Profil Kesehatan Kabupaten Bangkalan Tahun 2015.

Barlow, J., \& Coren, E. (2018). The Effectiveness of Parenting Programs: A Review of Campbell Reviews. Research on Social Work Practice, 28(1), 99-102. https:/ / doi.org/10.1177/1049731517725184

Bergström, H., Haggård, U., Norman, Å., Sundblom, E., Elinder, L. S., \& Nyberg, G. (2015). Factors influencing the implementation of a school-based parental support programme to promote health-related behaviours-interviews with teachers and parents. BMC Public Health, 15(1), 541.

Child Welfare Information Gateway. (2013). Parent education to strengthen families and reduce the risk of maltreatment. (September).

Council, N. R. (2015). Transforming the workforce for children birth through age 8: A unifying foundation. National Academies Press.

Fadzila, D. N., \& Tertiyus, E. P. (2019). Ketahanan Pangan Rumah Tangga Anak Stunting Usia 6-23 Bulan di Wilangan, Nganjuk. Amerta Nutrition, 3(1), 18. https://doi.org/10.20473/amnt.v3i1.2019.18-23

Hamzah, B., \& Koni, S. (2014). Assesment Pembelajaran. In Assessment Pembelajaran. Jakarta: Bumi Aksara.

Iriantara, Y., \& Soenendar, R. K. (2010). Literasi media: apa, mengapa, bagaimana. Jakarta: Simbiosa Rekatama Media.

Kementerian Desa, Pembangunan Daerah Tertinggal, dan T. (2017). Buku saku desa dalam penanganan stunting. In Buku Saku Desa Dalam Penanganan Stunting. Jakarta: Kementrian Desa, Pembangunan Daerah Tertinggal, dan Transmigrasi.

Lopez, P. ., Tjokrosonto, S., \& Paramastri, I. (2004). Promosi kesehatan pada kader posyandu dalam meningkatkan pengetahuan dan keterampilan tentang penanggulangan malaria di Kabupaten Timor Tengah Utara. Sains Kesehatan, 17(1), 77-87.

Moore, K. A. (2013). What is Child Well-being?: Does It Matter How We Measure It. Poster Session Presented at National Council on Family Relations Annual Conference.

Mukhtar. (2013). Metode Praktis Penelitian Deskriptif Kualitatif. Jakarta: GP Press Group.

Nahartyo, E. (2013). Desain dan Implementasi Riset Eksperimen, edisi kedua. Yogyakarta: UPP STIM YKPN.

Nurhidayati, A., \& Ernawati. (2016). Hubungan Tingkat Pengetahuan Ibu dengan Perilaku Pemenuhan Kebutuhan Nutrisi Selama Kehamilan. Jurnal KesMasDaSka, 153-157.

Primivita Dirgahayu, N. (2015). Hubungan Antara Tingkat Pengetahuan Dengan Perilaku Hidup Bersih Dan Sehat Siswa Di Madrasah Ibtidaiyah Muhammadiyah Gonilan Kartasura Sukoharjo. Doctoral Dissertation.

Rachmi, C. N., Li, M., \& Alison Baur, L. (2017). Overweight and obesity in Indonesia: prevalence and risk factors-a literature review. Public Health, 147, 20-29. https://doi.org/10.1016/j.puhe.2017.02.002

Radey, M., \& Randolph, K. A. (2009). Parenting sources: How do parents differ in their efforts to learn about parenting? Family Relations, 58(5), 536-548. https:/ / doi.org/10.1111/j.1741-3729.2009.00573.x

Rukmana, S. C. (2013). Hubungan asupan gizi dan status gizi ibu hamil trimester III dengan berat badan lahir bayi di wilayah kerja Puskesmas Suruh. Universitas 
Diponegoro Semarang.

Silas, L., Rantetampang, A. L., Tingginehe, R., \& Mallongi, A. (2018). The Factors Affecting Stunting Child under Five Years in Sub Province Mimika. International Journal of Science \& Healthcare Research, 3(2), 99-108.

Sudjana, N. (2010). Dasar-dasar Proses Belajar. In Bandung: Sinar Baru. Bbandung: Sinar Baru.

Sugiyono, P. (2001). Metode Penelitian Administrasi (edisi ke-3). Jakarta: Alfabeta.

Syahrul, S., Kimura, R., Tsuda, A., Susanto, T., Saito, R., \& Ahmad, F. (2016). Prevalence of underweight and overweight among school-aged children and it's association with children's sociodemographic and lifestyle in Indonesia. International Journal of Nursing Sciences, 3(2), 169-177. https://doi.org/10.1016/j.ijnss.2016.04.004

Tomlinson, H. B., \& Andina, S. (2015). Parenting Education in Indonesia: Review and Recommendations to Strengthen Programs and Systems. https://doi.org/10.1596/978-1-4648-0621-6

UNICEF. (2013). Profil singkat provinsi : Jawa Timur.

World Health Organization. (2010). Nutrition Landscape Information System (NLIS): Country Profile Indicators. https:// doi.org/10.1159/000362780.Interpretation

Wrottesley, S. V, Lamper, C., \& Pisa, P. T. (2016). Review of the importance of nutrition during the first 1000 days: maternal nutritional status and its associations with fetal growth and birth, neonatal and infant outcomes among African women. Journal of Developmental Origins of Health and Disease, 7(2), 144162. https:// doi.org/10.1017/S2040174415001439

Zoellner, J., You, W., Connell, C., Smith-Ray, R. L., Allen, K., Tucker, K. L., ... Estabrooks, P. (2011). Health Literacy Is Associated with Healthy Eating Index Scores and Sugar-Sweetened Beverage Intake: Findings from the Rural Lower Mississippi Delta. Journal of the American Dietetic Association, 111(7), 1012-1020. https://doi.org/10.1016/j.jada.2011.04.010 